\section{New patient-reported outcome measure to assess perceived barriers to antiretroviral therapy adherence: the PEDIA scale}

\author{
Uma nova medida de desfecho relatada pelo \\ paciente para avaliar barreiras percebidas à \\ adesão à terapia antirretroviral: a escala PEDIA
}

\section{Una nueva medida de resultados apreciados por pacientes para evaluar los obstáculos percibidos en la adherencia a la terapia antirretroviral: la escala PEDIA}

Celline Cardoso Almeida-Brasil 1

Elizabeth do Nascimento 1

Micheline Rosa Silveira 1

Palmira de Fátima Bonolo 1

Maria das Graças Braga Ceccato 1

doi: 10.1590/0102-311X00184218

\section{Correspondence}

C. C. Almeida-Brasil

Faculdade de Farmácia, Universidade Federal de Minas Gerais. Av. Antonio Carlos 6627, sala 1023 B2, Belo Horizonte, MG 31270-901, Brasil.

celline.cardoso@gmail.com

1 Universidade Federal de Minas Gerais, Belo Horizonte, Brasil After pilot testing and assessing the evidence based on content analysis, the scale's revisions resulted in a 40-item version. The PEDIA was applied to 415 $H I V$-infected adults receiving ART for a maximum of 180 days, recruited from three healthcare facilities of reference in the city of Belo Horizonte, Minas Gerais State, Brazil. The analyses included exploratory factor analysis, internal consistency, item response theory, temporal stability, and predictive test-criterion relationship. The scale's final version contains 18 items distributed in three dimensions, as follows: cognitive and routine problems (4 items); medication and health concerns (6 items); and patient's fears and feelings ( 8 items). The results of McDonald's omega and temporal stability demonstrate that the PEDIA is internally consistent and yields stable scores over time. The assessment of the information's functions suggested that the three dimensions were informative for assessing a broad range of latent traits. Evidence concerning the test-criterion relationship confirmed that the PEDIA was able to predict non-adherence three months later. Our findings suggest that the PEDIA is a psychometrically adequate tool for evaluating perceived barriers in adult patients initiating ART. It could be used in both research and clinical practice for the early detection of patients at risk of non-adherence and for the identification of potentially modifiable barriers.

Patient Reported Outcome Measures; Psychometrics; HIV Infections;

Medication Adherence 


\section{Introduction}

HIV infection is a significant contributor to morbidity and health-related costs worldwide 1. Brazil account for almost 50\% of HIV infection cases in Latin America, registering 14,000 HIV-related deaths per year 2. Antiretroviral therapy (ART) effectively improves immune reconstitution, prevents the emergence of drug resistance and decreases HIV transmission by more than 95\% 3,4,5. Although the advances in the ART regimens have significantly improved the patients' prognosis and quality of life, living with HIV still requires the use of lifelong daily medications, and a strict adherence is required to ensure the treatment's success.

Providers and researchers would welcome a simple, yet effective, screening tool to help them identify patients who may be at risk of suboptimal adherence. The identification of these cases and the application of interventions to improve adherence are especially important for patients at the beginning of treatment. Adherence in the beginning of treatment is an important predictor of future therapeutic success 6,7. Perceived barriers are one of the strongest predictors of nonadherent behavior 8 . As a social cognitive construct often incorporated in health behavior theories such as the Health Believe Model and the Theory of Planned Behavior, perceived barriers refer to a patient's personal estimation of social, personal and environmental obstacles to achieve a goal, such as medication adherence ${ }^{9}$. The identification of perceived barriers among people living with HIV/AIDS (PLWHA) could support the development of strategies to overcome difficulties and improve adherence 10.

Patients provide a unique perspective on the outcome being measured and self-report questionnaires have the advantage of obtaining the patient's perception directly without interpretation by a third party 11. Currently, patient-reported outcome measures (PROMs) are available for the individual assessment of behavioral constructs, such as regimen complexity, lack of social support and negative beliefs in relation to medication ${ }^{12}$. Although these instruments typically assess important factors believed to hinder the adherence to ART, they are not perceived barrier scales per se. In contrast, instruments developed specifically to assess barriers to ART adherence do not comprehensively describe the perceived barriers often reported in qualitative studies 13,14,15,16. For instance, the Structural Barriers to Medication-Taking scale does not evaluate pill burden/fatigue, negative beliefs about medication, lack of motivation, disruption in daily routine, or factors related to the healthcare system 17. Similarly, the Self-reported Barriers to Adherence does not evaluate substance abuse, complexity of therapy, or healthcare-related factors 18 . On the other hand, an instrument developed by Wohl et al. 19 (IRT-30) does a good job describing the perceived barriers construct, but is not a good predictor of non-adherence.

So far, no instrument has been developed to explore patient-specific barriers to ART adherence in Brazilians living with HIV. Thus, the purpose of this study was to develop and evaluate a new patient-reported outcome measure to evaluate perceived barriers among PLWHA at the beginning of antiretroviral treatment. We hypothesized that the measure may be able to predict nonadherence to ART. Predicting non-adherence can help stakeholders plan interventions before the treatment fails. Because certain perceived barriers have different degrees of relevance to different patients, this measure may also offer practical insights for behavioral interventions by adopting an individualized approach.

\section{Methods}

\section{Scale's development}

The Perceived Barriers to Antiretroviral Therapy Adherence - PEDIA scale - assesses the patients' perceptions of difficulties faced while managing ART. A list of 47 items was created based on the qualitative analysis of open-ended questions with 598 PLWHA from 17 health care centers across the five geopolitical regions of Brazil 20,21. Each item was formulated as a statement, as close as possible to the patients' words. After pilot testing and assessing the evidence based on content analysis and cognitive processes, the scale's revisions resulted in a 40 -item version 22 . Subsequently, we conducted face-toface cognitive interviews with 27 patients. The participants answered the questionnaire and assessed 
the items' clarity and comprehensibility, suggested rephrasing problematic items and made additional comments. The items were also modified in a consultation with a panel of three HIV treatment experts, including a physician, a pharmacist and a public health decision-maker. All three judges rated the items for the contents' relevance, dimensionality, and the appropriateness of the scale's format. Four dimensions were originally defined (Supplementary Material, Table S1: http://cadernos.ensp. fiocruz.br/site/public_site/arquivo/suppl-e00184218_1333.pdf): (1) emotional factors, representing the patient's feelings and beliefs; (2) social and economic factors, such as financial constraints and social support; (3) factors related to ART regimens, including side effects, physical characteristics of medicines, pill burden and routine disruptions; and (4) factors related to the healthcare facility and caregivers, representing the patient-caregiver relationship and the patient's perception of the care and services provided. These evaluations indicated the suitability of the scale's contents to the construct it intends to measure 22 .

The respondents were asked to rate their level of agreement with the statements about what makes it difficult for them to adhere to ART. In the pilot version of the PEDIA, the items were rated in a five-point Likert-type scale ranging from 1 to 5 , where $1=$ strongly disagree, $2=$ disagree, $3=$ neither agree nor disagree, $4=$ agree, and $5=$ strongly agree.

\section{Design and setting}

As part of a larger cohort study evaluating the effectiveness of ART in patients beginning treatment (ECOART study) 23, patients from three healthcare facilities in the city of Belo Horizonte, Minas Gerais State, Brazil, were recruited between September 2015 and October 2017 and followed-up for a maximum of six months. The three services are a reference in HIV treatment and, together, they are responsible for the treatment of $80 \%$ of PLWHA in Belo Horizonte.

\section{Participants}

The patients were eligible if they were HIV-infected adults ( $>18$ years old) receiving ART for a minimum of seven and a maximum of 180 days from one of the three services considered. Their time on ART was measured according to the patients' self-report and confirmed by analyzing their medical charts. The exclusion criteria included previous use of ART for prophylaxis and being too ill to participate.

The sample size's estimation considered 10 individuals per item of the version of the scale being tested (40-item version) - the suggested ratio for conducting factor analysis 24,25 - and $20 \%$ loss ( $\mathrm{n}=$ 500). The participants were consecutively approached by the researchers to ask about their interest in participating, assess the eligibility criteria and obtain their informed consent. Patients who did not go to the healthcare facility for medical appointments or ART refill during the data collection period were not considered for inclusion.

\section{Procedures}

Ethics approval was granted by all participating institutions and the Federal University of Minas Gerais. All interviews were conducted in Portuguese, in private rooms inside the healthcare facilities, and they were identified by number for anonymity purposes.

After obtaining the participants' consent, we conducted face-to-face interviews using a self-report questionnaire. Participants with a complete baseline assessment were invited to return for a second interview approximately three months later, where we re-administered the PEDIA for the test-retest analysis and assessed their non-adherence for prediction of the test-criterion relationship.

\section{Measures}

The self-reported questionnaire assessed sociodemographic (i.e., age, sex, marital status, race, education and employment status), clinical (i.e., HIV viral load and CD4 count) and treatment-related characteristics (i.e., time on ART, ART regimen and adherence to treatment). 
The data on ART regimen, viral loads and CD4 count were extracted from two information systems of the Brazilian Ministry of Health, the Medication Logistics Control System (SICLOM) and the Laboratory Test Control System (SISCEL). Non-adherence to treatment was assessed at baseline and at the three-month follow-up by asking "Did you skip your HIV medication over the past 2 weeks?". Participants who answered "yes" were considered non-adherent.

\section{Analyses}

The descriptive statistics were computed in terms of number and frequency for categorical data and mean and standard deviation (SD) for continuous variables. We assessed differences in characteristics at the baseline between respondents and non-respondents of the follow-up interview using chisquared and t-tests.

Skewness and kurtosis were used to judge the normality of each item's distribution. For psychometric purposes, skewness and kurtosis values between -2 to +2 were considered acceptable 26 . A stepwise item selection procedure was used to refine the scale. The selection process was recursive and considered the results of internal consistency, exploratory factor analysis (EFA) and the item response theory (IRT).

Internal consistency was evaluated based on the item-total correlation coefficient. An item-total correlation coefficient equal to 0.3 is the minimum recommended for items in a new scale 25 . Reliability was assessed using McDonald's omega ( $\omega$ ) 27 . This estimator is suitable even when items with different factor loadings are present in the representation of the construct 28 . A $\omega$ value equal to 0.75 or higher is suggested for a composite score to provide unique, reliable variance 29.

We performed an exploratory factor analysis of the selected items to analyze the PEDIA's internal structure. The Hull method was used to determine the number of factors in the instrument 30 . We used the polychoric correlation matrix and performed EFA with the unweighted least squares estimator and promax rotation 31,32 . Items with loadings greater than 0.3 in only one factor were retained 33. Complex items, i.e., those with similar loadings in two or more factors, were excluded.

In the item response theory model, the items were evaluated using Samejima's graded response model (GRM) for each unidimensional set of items 34. In this model, the items' responses were used to estimate the person's score in the latent trait, indicating how well the item discriminates (distinguishes) differences between individuals over the latent trait 35 . The items were selected based on their discrimination "a" ( $\mathrm{a}>0.65)$ and difficulty "b" $(-3<\mathrm{b}<+3) 36$. To allow a visual evaluation, we plotted Test Information Functions (which indicate how well the scale estimates perceived barriers over the whole range of latent trait), Item Characteristic Curves (which allow us to visually evaluate each item's discrimination and difficulty) and Category Characteristic Curves (which display the probability of selecting each category of response at various levels of the latent trait).

Temporal stability was assessed based on the test-retest correlation and invariance in scores over time 24 . The intraclass correlation coefficient (ICC) estimates and their 95\% confident intervals $(95 \% \mathrm{CI})$ were calculated according to a mean-rating $(\mathrm{k}=2)$, absolute-agreement, 2 -way mixed-effects model. ICC values lower than 0.5 are indicative of poor reliability, values between 0.5 and 0.75 indicate moderate reliability, values between 0.75 and 0.9 indicate good reliability, and values greater than 0.90 indicate excellent reliability 37 . Stability was further assessed by comparing the baseline and three months post-baseline mean PEDIA scores using paired-samples t-test. Comparisons not significant at the $5 \%$ level $(\mathrm{p}>0.05)$ suggest the measure's stability.

To provide evidence that the instrument's scores predict the criterion's performance (i.e., nonadherence), we conducted binary logistic regressions with non-adherence at the three-month followup as the dependent variable and the PEDIA scores as the independent variables. The analysis was controlled by age, sex, marital status, race, education, employment status, viral load, CD4 count, time on ART, ART regimen and non-adherence at the baseline. The association was expressed in terms of adjusted odds ratios (aOR) with $95 \%$ CI.

Analyses of internal consistency, IRT, temporal stability and test-criterion relationship were conducted in Stata version 14 (https://www.stata.com). EFA was conducted using FACTOR 10.7 (http://psico.fcep.urv.es/utilitats/factor/Download.html) and reliability was estimated using OMEGA (http://edpsychassociates.com/Watkins3.html). 


\section{Results}

\section{Sample's characteristics}

A total of 507 patients were approached to participate in the study. Most individuals were excluded due to their time on ART; 37 had been on it for less than seven days and 16 for more than 180 days. Five individuals were excluded due to previous use of ART. Of 449 eligible individuals, 33 declined participating for being "too busy" or not interested and one did not complete the interview, resulting in a total of 415 individuals included.

Table 1 displays the characteristics of the participants. The mean age was $34.6(\mathrm{SD}=10.9)$, and $81 \%$ were male. Most participants were adherent to ART (84\%) and the prevalence of detectable viral load (> 50 copies $/ \mathrm{mL}$ ) was high (94\%). Most participants had been using the once-a-day single-tablet regimen of tenofovir disoproxil fumarate (TDF), lamivudine (3TC) and efavirenz (EFV), which was the first-line regimen adopted in Brazil between January 2015 and December 2016. As of January 2017, the first-line regimen changed to TDF + 3TC and dolutegravir (DTG), which was used by $31 \%$ of our sample.

Table 1 also presents the baseline characteristics of the subsample of participants who returned for the follow-up interview ( $\mathrm{n}=355)$, which took place approximately three months after the baseline visit. Of the 60 participants lost, 4 died, 12 withdrew their consent, 7 abandoned care, 6 were transferred to another healthcare facility and $31 \mathrm{did}$ not return for the follow-up. There was no difference in the patients' baseline characteristics between respondents and non-respondents of the follow-up interview (Table 1).

\section{PEDIA evaluation}

Most participants were able to fill in the scale within 10 minutes. All participants answered at least $80 \%$ of the PEDIA's items and were therefore included in further analyses. The initial item analysis stage included examining the answer categories' frequency distribution. Most items showed little variability in their answer patterns. Also, the analysis of the Category Characteristic Curves confirmed that the participants had difficulty discriminating between answer categories. For each item, some categories

\section{Table 1}

Baseline characteristics of the total sample and the follow-up subsample.

\begin{tabular}{|c|c|c|c|c|}
\hline \multirow[t]{2}{*}{ Characteristic } & \multirow{2}{*}{$\begin{array}{c}\text { Total sample } \\
(\mathbf{N}=\mathbf{4 1 5})\end{array}$} & \multicolumn{3}{|c|}{ Follow-up subsample } \\
\hline & & $\begin{array}{l}\text { Respondents } \\
\quad(n=355)\end{array}$ & $\begin{array}{l}\text { Non-respondents } \\
\qquad(n=60)\end{array}$ & p-value \\
\hline \multicolumn{5}{|l|}{ Sociodemographic } \\
\hline Age (mean \pm SD) & $34.64 \pm 10.95$ & $34.95 \pm 10.99$ & $32.90 \pm 10.65$ & 0.18 \\
\hline Sex (\% male) & $336(81.16)$ & $290(81.92)$ & $46(76.67)$ & 0.34 \\
\hline Marital status (\% married) & $86(20.72)$ & $76(21.41)$ & $10(16.67)$ & 0.40 \\
\hline Race (\% white) & $99(23.86)$ & $81(22.82)$ & $18(30.00)$ & 0.23 \\
\hline Education ( $\% \geq$ high school) & $280(67.63)$ & $238(67.23)$ & $42(70.00)$ & 0.67 \\
\hline Employment status (\% working) & $254(61.20)$ & $211(59.44)$ & $43(71.67)$ & 0.07 \\
\hline \multicolumn{5}{|l|}{ Clinical } \\
\hline Viral load ( $\%>50$ copies $/ m L)$ & $327(94.24)$ & $286(95.02)$ & $41(89.13)$ & 0.11 \\
\hline CD4 count $(\%<200$ cells $/ \mu \mathrm{L})$ & $87(26.77)$ & $76(26.76)$ & $11(26.83)$ & 0.99 \\
\hline \multicolumn{5}{|l|}{ Treatment } \\
\hline Time on ART (months; mean \pm SD) & $2.83 \pm 1.94$ & $2.79 \pm 1.92$ & $3.00 \pm 2.08$ & 0.43 \\
\hline ART regimen (\% single-tablet) & $253(60.96)$ & $216(60.85)$ & $37(61.67)$ & 0.90 \\
\hline Non-adherence ( $\%$ yes) & $66(15.98)$ & $53(15.01)$ & $13(21.67)$ & 0.19 \\
\hline
\end{tabular}

ART: antiretroviral therapy; SD: standard deviation. 
were never the most probable answer. When the range of available answer categories obscures rather than clarifies the intent of the respondent, one strategy is to collapse the data across categories 38,39 . Therefore, the answer categories were reduced from five to three 40 . The categories "totally disagree" and "partially disagree" were recoded into "disagree", "totally agree" and "partially agree" were recoded into "agree", and the category "neither agree nor disagree" remained as the original.

Table 2 displays all the 40 items and their characteristics. The agreement was higher in positively phrased items, such as item 15 . Before further analyses, these items were reverse coded so that a higher mean score would indicate more perceived barriers. The two items with the higher mean scores (items 2 and 25) were both related to stigma. Given that the answer format is categorical, the item distributions were expected to demonstrate some degree of non-normality. High levels of skewness and kurtosis occurred in items 1, 5, 6, 14, 15, 16, 21, 23, 25, 26, 27, 31, 38 and 39 (Supplementary Material, Table S1: http://cadernos.ensp.fiocruz.br/site/public_site/arquivo/suppl-e00184218_1333.pdf). These items were considered for potential exclusion from the PEDIA, but the decision had to be made also considering the results of the item-total correlation and the EFA.

In all, 25 out of 40 items fulfilled the minimum item-total correlation coefficient value of 0.3 (Table 2). The other 15 items did not meet the selection criteria and were thus removed (items 1, 9, $10,15,16,19,21,22,24,27,31,32,33,38$ and 39). The Kaiser-Meyer-Olkin index (KMO = 0.77) and significance in Bartlett's test of sphericity $(\mathrm{p}<0.001)$ indicated that the correlation matrix of the 25 items retained was adequate for the EFA. The Hull method suggested the extraction of three factors, which together explained $31.2 \%$ of the total variance. Notably, five items did not load strongly on any of the three factors, and two items loaded onto two factors with similar factor loading values (Table 2). These seven items were thus removed (items 11, 20, 26, 28, 34, 35 and 37), resulting in a final 18-item version.

All factors were well-defined by the items. The first factor reflects "cognitive and routine problems", and it included four items representing the patients' cognition problems to remember taking the pills and fit the treatment into their daily routines. The second factor had six items about side effects (real or anticipated), physical characteristics of the drugs and functionality, and was labeled "medication and health concerns". The third factor was named "patient's fears and feelings", and it included eight items related mainly to stigma, such as fear of disclosure, but also to pill fatigue and future concerns about treatment. The inter-factor correlation varied from 0.35 to 0.44 , suggesting that each factor represented a distinct dimension and that there was low redundancy between dimensions.

McDonald's $\omega$ for the final scale was 0.97 and demonstrated good reliability. For the first dimension (cognitive and routine problems), $\omega$ was 0.92 . For the second (medication and health concerns) and third (patient's fears and feelings) dimensions, $\omega$ was 0.94 .

Regarding the item response theory, all 18 items satisfied the condition of $a>0.65$ and $3<b<+3$ (Table 2). They offered great discrimination potential, with parameters ranging from 0.73 to 2.13 . In the dimension of cognitive and routine problems, the highest discriminating item was item 13 . In terms of item difficulty, "b" values ranged from 0.72 to 1.72 , reflecting moderate levels of difficulty. In the medication and health concerns dimension, the highest discriminating item was item 5. Items 6 and 14, both positively phrased items, were associated with higher levels of difficulty. Consistently, less than $10 \%$ of the respondents answered "disagree" in each of these items. Similarly, their observed means were also lower than those of the other items (Table 2). In the patient's fear and feelings dimension, the highest discriminating item was item 36. In terms of item difficulty, "b" values ranged from -2.50 to 0.78 , reflecting low to moderate levels of severity.

The Test Information Functions are shown in Figure 1. For the dimension of cognitive and routine problems, information was good for scores between 0 and 2.5 (between the mean and two and a half standard deviations above the mean). The dimension of medication and health concerns was more informative in assessing the respondents whose scores in the theta continuum ranged approximately between 0 and 3. The patient's fears and feelings dimension was more informative in assessing the respondents whose scores ranged approximately between -2 and +2 (between two standard deviations below the mean and two standard deviations above the mean).

The three-month test-retest reliability method yielded an ICC equal to 0.52 (95\%CI: $0.41,0.61$ ). There was no significant difference between the participants' total scores at the baseline (M0 = 30.81 $\pm 6.01)$ and three months later $(M 3=30.27 \pm 6.00)$, $(\mathrm{p}=0.27)$. The same occurred for each of the 
Table 2

Descriptive statistics and parameters of items of the PEDIA scale $(N=415)$.

\begin{tabular}{|c|c|c|c|c|c|c|c|c|c|c|c|c|}
\hline \multirow[t]{2}{*}{ Item } & \multicolumn{3}{|c|}{$\begin{array}{l}\text { Observed response } \\
\text { frequencies }(\%) \text { * }\end{array}$} & \multicolumn{3}{|c|}{$\begin{array}{l}\text { Classic item } \\
\text { statistics ** }\end{array}$} & \multicolumn{3}{|c|}{ Factor loading *** } & \multicolumn{3}{|c|}{$\begin{array}{l}\text { Item parameter } \\
\text { estimates \# }\end{array}$} \\
\hline & 1 & 2 & 3 & M & SD & $r$ & F1 & F2 & F3 & a & b1 & b2 \\
\hline $\begin{array}{l}\text { 1. Sometimes I do not take my HIV meds } \\
\text { if I use alcohol or any illicit substance }\end{array}$ & 92.49 & 1.55 & 5.96 & 1.13 & 0.41 & 0.10 & - & - & - & - & - & - \\
\hline $\begin{array}{l}\text { 2. The main problem of living with HIV is } \\
\text { the stigma around it }\end{array}$ & 15.90 & 6.75 & 77.35 & 2.61 & 0.61 & 0.31 & 0.11 & -0.13 & 0.43 & 0.73 & -2.50 & -1.85 \\
\hline $\begin{array}{l}\text { 3. I am afraid to be identified as HIV } \\
\text { positive when I go to the healthcare } \\
\text { facility to get my HIV meds refill }\end{array}$ & 37.11 & 8.19 & 54.70 & 2.18 & 1.02 & 0.42 & 0.06 & -0.18 & 0.58 & 1.29 & -0.53 & -0.18 \\
\hline $\begin{array}{l}\text { 4. It frustrates me to think that I need to } \\
\text { take the HIV meds in order to be alive }\end{array}$ & 52.90 & 12.08 & 35.02 & 1.82 & 0.81 & 0.43 & 0.18 & 0.06 & 0.32 & 0.95 & 0.16 & 0.79 \\
\hline $\begin{array}{l}\text { 5. Sometimes I skip taking my HIV meds } \\
\text { because I want to avoid side effects }\end{array}$ & 93.45 & 1.70 & 4.85 & 1.11 & 0.41 & 0.33 & 0.02 & 0.57 & -0.14 & 2.13 & 1.96 & 2.17 \\
\hline $\begin{array}{l}\text { 6. Despite my HIV status, I live a normal } \\
\text { life }\end{array}$ & 9.40 & 5.06 & 85.54 & 1.24 & 0.61 & 0.30 & -0.07 & 0.40 & -0.12 & 1.11 & 1.94 & 2.44 \\
\hline $\begin{array}{l}\text { 7. It is difficult to take my HIV meds at } \\
\text { home }\end{array}$ & 83.37 & 2.89 & 13.73 & 1.30 & 0.61 & 0.31 & 0.54 & 0.01 & 0.02 & 1.43 & 1.52 & 1.72 \\
\hline $\begin{array}{l}\text { 8. I do not like to take my HIV meds } \\
\text { around others }\end{array}$ & 56.50 & 9.50 & 34.00 & 1.78 & 1.02 & 0.50 & 0.24 & 0.00 & 0.37 & 1.08 & 0.30 & 0.76 \\
\hline $\begin{array}{l}\text { 9. Family or friends make sure I am taking } \\
\text { the HIV meds correctly }\end{array}$ & 66.67 & 4.20 & 29.14 & 2.38 & 0.81 & 0.12 & - & - & - & - & - & - \\
\hline $\begin{array}{l}\text { 10. The use of electronic devices, such as } \\
\text { alarm clocks, reminds me to take my HIV } \\
\text { meds consistently }\end{array}$ & 53.10 & 3.97 & 42.93 & 2.10 & 1.02 & 0.13 & - & - & - & - & - & - \\
\hline $\begin{array}{l}\text { 11. I am worried about the reactions } \\
\text { between my HIV meds and the } \\
\text { medications I take for other diseases }\end{array}$ & 58.64 & 6.02 & 35.34 & 1.77 & 1.02 & 0.40 & 0.00 & 0.14 & 0.24 & - & - & - \\
\hline $\begin{array}{l}\text { 12. Sometimes I forget to take my HIV } \\
\text { meds because I get distracted }\end{array}$ & 68.12 & 3.14 & 28.74 & 1.61 & 0.81 & 0.36 & 0.61 & -0.04 & -0.01 & 1.50 & 0.72 & 0.85 \\
\hline $\begin{array}{l}\text { 13. It is difficult to take my HIV meds at } \\
\text { work }\end{array}$ & 77.54 & 5.88 & 16.58 & 1.39 & 0.81 & 0.41 & 0.49 & 0.02 & 0.14 & 2.06 & 1.01 & 1.30 \\
\hline $\begin{array}{l}\text { 14. I believe that my HIV meds make me } \\
\text { healthy }\end{array}$ & 5.30 & 9.40 & 85.30 & 1.20 & 0.41 & 0.37 & 0.14 & 0.43 & -0.07 & 1.20 & 1.81 & 2.88 \\
\hline $\begin{array}{l}\text { 15. I appreciate the fact that the HIV } \\
\text { meds are provided free of charge }\end{array}$ & 0.48 & 0.72 & 98.79 & 1.02 & 0.20 & 0.14 & - & - & - & - & - & - \\
\hline $\begin{array}{l}\text { 16. I appreciate when I get the chance } \\
\text { to talk longer with my doctor during the } \\
\text { appointment }\end{array}$ & 2.17 & 3.62 & 94.20 & 1.08 & 0.41 & 0.03 & - & - & - & - & - & - \\
\hline $\begin{array}{l}\text { 17. It is tiresome to take my HIV meds } \\
\text { everyday }\end{array}$ & 53.49 & 6.75 & 39.76 & 1.86 & 1.02 & 0.54 & 0.10 & 0.23 & 0.36 & 1.41 & 0.14 & 0.41 \\
\hline 18. I find it difficult to swallow the pills & 79.47 & 5.07 & 15.46 & 1.36 & 0.81 & 0.32 & -0.05 & 0.48 & -0.10 & 1.04 & 1.56 & 1.95 \\
\hline $\begin{array}{l}\text { 19. I make a link between my HIV meds } \\
\text { and some activity in my routine so I can } \\
\text { remember to take them on time }\end{array}$ & 30.12 & 5.06 & 64.82 & 1.65 & 0.81 & 0.12 & - & - & - & - & - & - \\
\hline $\begin{array}{l}\text { 20. There is not enough money for } \\
\text { adequate food }\end{array}$ & 64.25 & 8.21 & 27.54 & 1.63 & 0.81 & 0.32 & 0.17 & 0.19 & -0.02 & - & - & - \\
\hline $\begin{array}{l}\text { 21. The staff at the healthcare facility } \\
\text { treats me well }\end{array}$ & 2.41 & 2.89 & 94.70 & 1.08 & 0.41 & 0.15 & - & - & - & - & - & - \\
\hline
\end{tabular}

(continues) 


\begin{tabular}{|c|c|c|c|c|c|c|c|c|c|c|c|c|}
\hline \multirow[t]{2}{*}{ Item } & \multicolumn{3}{|c|}{$\begin{array}{l}\text { Observed response } \\
\text { frequencies }(\%) \text { * }\end{array}$} & \multicolumn{3}{|c|}{$\begin{array}{l}\text { Classic item } \\
\text { statistics ** }\end{array}$} & \multicolumn{3}{|c|}{ Factor loading *** } & \multicolumn{3}{|c|}{$\begin{array}{l}\text { Item parameter } \\
\text { estimates \# }\end{array}$} \\
\hline & 1 & 2 & 3 & $M$ & SD & $r$ & F1 & F2 & F3 & $a$ & b1 & b2 \\
\hline $\begin{array}{l}\text { 22. Talking with others about HIV helps } \\
\text { me to keep taking the meds }\end{array}$ & 30.37 & 12.10 & 57.53 & 1.73 & 0.81 & 0.11 & - & - & - & - & - & - \\
\hline $\begin{array}{l}\text { 23. When I feel depressed I do not want } \\
\text { to take my HIV meds }\end{array}$ & 90.27 & 1.95 & 7.79 & 1.18 & 0.61 & 0.44 & 0.26 & 0.48 & -0.08 & 1.95 & 1.74 & 1.91 \\
\hline $\begin{array}{l}\text { 24. I enjoy sharing experiences with } \\
\text { others living with HIV }\end{array}$ & 38.76 & 16.54 & 44.70 & 1.94 & 1.02 & 0.16 & - & - & - & - & - & - \\
\hline $\begin{array}{l}\text { 25. It is difficult to tell people that I am } \\
\text { HIV positive }\end{array}$ & 11.57 & 4.34 & 84.10 & 2.72 & 0.61 & 0.32 & -0.02 & -0.19 & 0.49 & 1.19 & -2.11 & -1.74 \\
\hline $\begin{array}{l}\text { 26. I feel that the healthcare facility } \\
\text { personnel have stigmatizing attitudes } \\
\text { towards patients }\end{array}$ & 83.78 & 4.60 & 11.62 & 1.28 & 0.61 & 0.31 & 0.12 & 0.20 & 0.04 & - & - & - \\
\hline $\begin{array}{l}\text { 27. My doctor encourages me to take my } \\
\text { HIV medications }\end{array}$ & 2.17 & 1.45 & 96.39 & 1.06 & 0.41 & 0.12 & - & - & - & - & - & -- \\
\hline $\begin{array}{l}\text { 28. The HIV meds bring out bad feelings } \\
\text { because they remind me I am HIV } \\
\text { positive }\end{array}$ & 46.02 & 10.84 & 43.13 & 1.97 & 1.02 & 0.54 & -0.10 & 0.40 & 0.40 & - & - & - \\
\hline $\begin{array}{l}\text { 29. I am worried about the HIV meds } \\
\text { stopping to work in the future }\end{array}$ & 30.36 & 10.36 & 59.28 & 2.29 & 0.81 & 0.36 & -0.06 & 0.07 & 0.31 & 0.76 & -1.21 & -0.54 \\
\hline 30. It is hard to get used to the side effects & 54.77 & 9.29 & 35.94 & 1.81 & 1.02 & 0.38 & 0.01 & 0.48 & -0.03 & 1.51 & 0.19 & 0.54 \\
\hline $\begin{array}{l}\text { 31. I take my HIV medication because I } \\
\text { want to live }\end{array}$ & 0.96 & 2.41 & 96.63 & 1.04 & 0.20 & 0.12 & - & - & - & - & - & - \\
\hline $\begin{array}{l}\text { 32. I have a hard time getting a new job } \\
\text { because of my HIV status }\end{array}$ & 76.72 & 12.70 & 10.58 & 1.34 & 0.61 & 0.23 & - & - & - & - & - & - \\
\hline $\begin{array}{l}\text { 33. There is no proposal of support } \\
\text { groups at the healthcare facility }\end{array}$ & 50.39 & 22.86 & 26.75 & 1.76 & 0.81 & 0.24 & - & - & - & - & - & - \\
\hline $\begin{array}{l}\text { 34. There is not enough money for the } \\
\text { transport to the healthcare facility }\end{array}$ & 72.22 & 5.80 & 21.98 & 1.50 & 0.81 & 0.30 & 0.27 & 0.23 & -0.19 & - & - & - \\
\hline $\begin{array}{l}\text { 35. It is hard to schedule medical } \\
\text { appointments and laboratory tests at the } \\
\text { healthcare facility }\end{array}$ & 68.67 & 6.99 & 24.34 & 1.56 & 0.81 & 0.35 & 0.14 & 0.20 & 0.00 & - & - & - \\
\hline $\begin{array}{l}\text { 36. It bothers me that I have to get my } \\
\text { HIV meds refill in the healthcare facility's } \\
\text { pharmacy }\end{array}$ & 49.88 & 8.43 & 41.69 & 1.92 & 1.02 & 0.47 & 0.05 & -0.05 & 0.53 & 1.80 & 0.00 & 0.29 \\
\hline 37. I have accepted the diagnosis of HIV & 32.45 & 14.04 & 53.51 & 1.79 & 0.81 & 0.45 & -0.24 & 0.32 & 0.38 & - & - & - \\
\hline $\begin{array}{l}\text { 38. I take my HIV medication as } \\
\text { prescribed so I will not feel ill }\end{array}$ & 0.72 & 1.45 & 97.83 & 1.03 & 0.20 & 0.16 & - & - & - & - & - & - \\
\hline $\begin{array}{l}\text { 39. I believe that the HIV meds can } \\
\text { reduce the amount of HIV virus in my } \\
\text { blood }\end{array}$ & 0.73 & 7.04 & 92.23 & 1.08 & 0.20 & 0.26 & - & - & - & - & - & - \\
\hline $\begin{array}{l}\text { 40. It is harder to keep track of my HIV } \\
\text { meds on weekends }\end{array}$ & 73.73 & 6.27 & 20.00 & 1.46 & 0.81 & 0.42 & 0.31 & 0.05 & 0.15 & 1.04 & 1.23 & 1.63 \\
\hline
\end{tabular}

M: mean; r: item-total correlation; SD: standard deviation.

Notes: b1 and b2 = item severity parameter estimates.

* Response score categories contain: 1 = "disagree", 2 = "neither agree nor disagree", 3 = "agree";

** The scores of positively phrased items were reversed so that higher scores denote higher perceived barriers;

$\star \star *$ F1 = cognitive and routine problems, F2 = medication and health concerns, F3 = patients' fears and feelings;

\# $\mathrm{a}=$ item discrimination parameter estimates. 

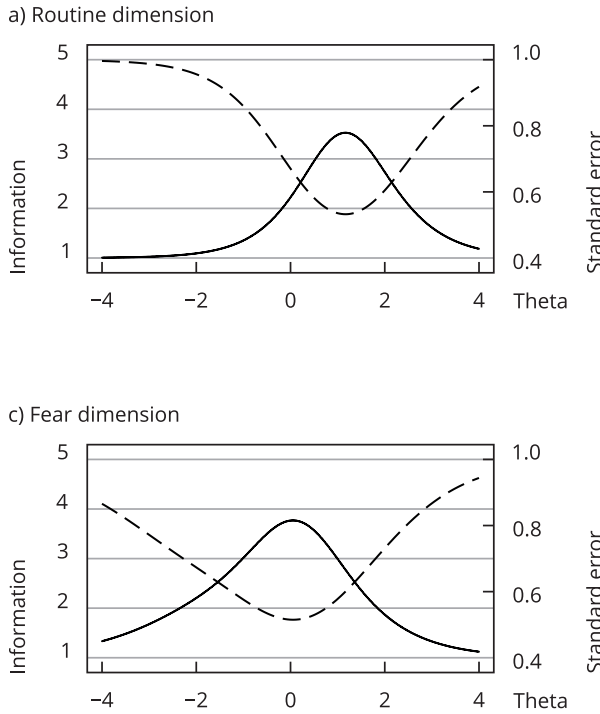
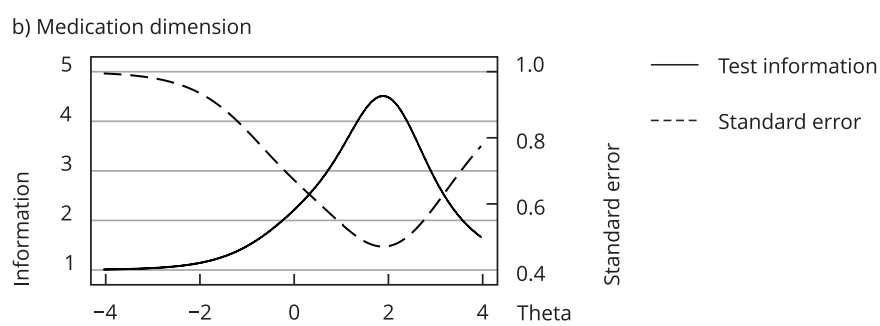

three dimensions: cognitive and routine problems $(\mathrm{M0}=5.74$ vs. $\mathrm{M} 3=5.76 ; \mathrm{p}=0.88)$; medication and health concerns $(\mathrm{M} 0=7.87$ vs. $\mathrm{M} 3=7.61 ; \mathrm{p}=0.12)$; and patient's fears and feelings $(\mathrm{M} 0=17.26$ vs. $\mathrm{M} 3$ = 17.16; $\mathrm{p}=0.75$ ).

The evidence concerning the test-criterion relationship confirmed that the PEDIA was able to predict non-adherence. Independently of the other participants' characteristics, the odds of being non-adherent after three months was significantly higher for participants who scored 1 point more in the total scale $(\mathrm{aOR}=1.12 ; 95 \% \mathrm{CI}: 1.05,1.21)$ and in each dimension: cognitive and routine problems $(\mathrm{aOR}=1.23$; 95\%CI: 1.01, 1.49); medication and health concerns $(\mathrm{aOR}=1.25 ; 95 \% \mathrm{CI}: 1.08,1.45)$; and patient's fears and feelings (aOR $=1.13$; 95\%CI: 1.01, 1.26).

The final version of the PEDIA (in Portuguese), together with instructions on how to compute the scale's scores, is available in the Supplementary Material (http://cadernos.ensp.fiocruz.br/site/ public_site/arquivo/suppl-e00184218_1333.pdf).

\section{Discussion}

This study presents the development of a new patient-reported outcome measure to evaluate perceived barriers in patients on ART, the PEDIA scale. The 18-item PEDIA is a brief and simple tool that can help caregivers identify patients with poor adherence and develop individualized strategies to meet these patients' needs.

An important specificity of the PEDIA is that the perceived barriers are measured from the "what makes it difficult to take your medication" perspective, rather than assessing quantity or frequency, i.e., "how often or how much a given barrier has prevented you from taking your medication", as in other tools for evaluation of barriers to adherence 17,18. This perspective gives PEDIA the advantage of measuring circumstances that could hinder adherence to therapy in the future (non-adherence has not necessarily occurred), rather than measuring reasons for skipping the medication (non-adherence has already occurred). 
Findings suggest that, rather than reflecting a single unified construct, the perceived barriers encompass multiple dimensions, which corroborates theoretical concepts about medication-taking behaviors 9,41. Although the PEDIA's pilot identified four dimensions (Supplementary Material, Table S1: http://cadernos.ensp.fiocruz.br/site/public_site/arquivo/suppl-e00184218_1333.pdf), only three were supported by the EFA. Other studies on the development and validation of scales also observed that the dimensions designed originally were not the same as the final dimensions 42,43. Each of the three dimensions is conceptually equivalent to one of the original four dimensions or a combination of two. The dimension of cognitive and routine problems and the dimension of medication and health concerns are equivalent to the original dimension of factors related to ART regimens. On the other hand, the patient's fears and feelings dimension is equivalent to the original dimensions of emotional and social factors.

The items initially assigned to the dimensions representing economic and healthcare-related factors were not included in the PEDIA's final version. A possible reason for this finding is that, in Brazil, a national healthcare system provides universal medical care and medications to HIV-infected people. In these circumstances, patients may be grateful for the free service provided and may not perceive financial aspects or healthcare-related factors as potential barriers to their adherence to treatment. Further research is needed to explore this hypothesis.

It is important to note that the refinement of the measure was a dynamic process, involving both quantitative and qualitative approaches. Before being excluded, items with item-total correlation $<0.30$ were subjected to a detailed analysis, which took in consideration the item's theoretical relevance. Items 9, 10, 19, 22 and 24, however, showed poor discrimination and low acceptance by the respondents, as observed using the Item and Category Characteristic Curves, and were therefore removed. The other items were added in the factor analysis and several attempts were made. The factorial solution with 18 items was the most robust and provided the greatest explanation of the variance.

The results of the IRT analysis suggested that some barriers are stronger discrimination indicators than others. For instance, items 5 ("Sometimes I skip taking my HIV meds because I want to avoid side effects"), 13 ("It is difficult to take my HIV meds at work") and 23 ("When I feel depressed I do not want to take my HIV meds") were found to have higher discriminating power. Caregivers may need to pay special attention to these barriers seeing as they are particularly useful to differentiate varied levels of the latent trait. The performance of the Test Information Functions suggested that the patient's fears and feelings dimension was informative in assessing a broad range of the latent trait. The other two dimensions offered great potential for assessing the higher level of the latent trait, and can thus be particularly useful for screening high-risk individuals with elevated latent trait levels.

In the logistic regression analyses, the odds of being non-adherent in the future were shown to increase as the PEDIA scores increased. Regardless of other important factors, such as adherence at the baseline, education and time on ART, the construct measured by the PEDIA scale had an impact on future adherence. The ability to predict non-adherence is a cornerstone of the treatment's success, seeing as non-adherence to ART is a central factor leading to incomplete viral suppression 44 . Furthermore, our results suggest that different types of barriers may show different behaviors in relation to non-adherence. The odds ratio for the dimensions of medication and health concerns and cognitive and routine problems were higher than the odds for the patient's fears and feelings dimension. Although the patient's fears and feelings dimension had the weakest association with non-adherence, concerns with stigma revealed to be prominent barriers to adherence in our sample.

The results of McDonald's $\omega$ and temporal stability demonstrate that the PEDIA is internally consistent and yields stable scores over time. Regarding the test-retest correlation, ICC indicated moderate reliability. As perceived barriers are expected to vary over time, we would expect only moderate levels of test-retest correlation. Shorter test-retest time intervals should produce somewhat higher correlations than longer intervals.

Gerend et al. 8 argue that ignoring the multidimensionality of perceived barriers by operationalizing them as a single composite unit may obscure critical information about the differential salience of specific barriers. Indeed, our logistic regression analysis showed that each dimension had a different impact on non-adherence. Therefore, we highlight the importance of evaluating each dimension separately rather than considering the overall score only. 
This study had some limitations. Firstly, the confirmatory factor analysis was not conducted. Thus, the factor analysis results presented here should be considered exploratory and additional work is needed to confirm these assessments. Secondly, from the 15 items excluded due to low item-total correlation, 12 were positively-phrased items representing facilitators of treatment adherence. This result suggests that the facilitators are not necessarily mirroring the lack of barriers, as we initially thought. Thirdly, although the PEDIA was designed based on reports of both individuals with experience with ART and those initiating the therapy, evidence associated with its internal structure was evaluated using data from patients at the beginning of treatment only. This occurred because the validation process was part of a larger cohort study, which included patients initiating ART to obtain a homogeneous sample and detect the first event of treatment failure. The PEDIA was then administered to this population to evaluate its ability to predict non-adherence before treatment failure occurs. However, the PEDIA's items represent perceived barriers in all phases of treatment and, therefore, it could be administered to individuals at any point of their treatment. It is important to note that a first indication of the instrument's validity has been obtained with the present study. A measure's validation process is dynamic, and evidence accumulates over time for different groups. Therefore, further verification of the PEDIA's reliability and evidence of its validity will be necessary when using it in populations with experience with ART. Fourthly, we used self-reported non-adherence as variable, and there might be objective measures which are more suitable. However, the self-reported questionnaire was chosen because it is strongly correlated with detectable viral load measured six months later (data not shown).

A major strength of the PEDIA is that its items reflect multiple varied barriers identified by PLWHA with different backgrounds and characteristics in Brazil. Besides the fact that its list of items was developed using a national study, the sociodemographic and clinical characteristics as well as the prevalence of non-adherence to ART in our sample were similar to those of other studies in the Brazilian population using ART 45,46,47. Another strength of our study is that the subsample size of 355 participants demonstrated enough power (> 80\%) to identify significant differences (5\% level) in the mean PEDIA scores between adherent and non-adherent participants.

The construct "perceived barriers" is particularly pertinent because it is potentially modifiable. The PEDIA's structure allows the evaluation and use of perceived barriers in three different ways: (1) general perceived barriers, by using the PEDIA's overall score. It could be used in the monitoring procedures for early identification of patients at risk of non-adherence; (2) three specific types of barriers, corresponding to the scores of each dimension. It may be used in the promotion of individualized care for identifying the specific barriers a patient needs to overcome; and (3) analysis of each item, corresponding to specific features within each dimension. It can be the basis for the development of behavior change interventions.

As a research tool, it may provide a valuable outcome variable, in addition to being used to compare the number and types of perceived barriers deemed as most relevant between adherent and non-adherent individuals. Finally, it can be used to assess the effectiveness of behavior change interventions. Using appropriate adaptation and translation procedures, the PEDIA may be adapted to evaluate the perceived barriers in other languages and cultures.

\section{Conclusions}

We have developed an 18-item patient-reported outcome measure with three dimensions, namely: cognitive and routine problems; medication and health concerns; and patient's fears and feelings. Our results suggest that the PEDIA is a psychometrically adequate tool for evaluating perceived barriers in adult patients initiating antiretroviral therapy in Brazil. In addition, it was suggested that the PEDIA may be useful for predicting non-adherence to ART. Future research will confirm the findings of this study with a wider population of patients in different contexts. The PEDIA could be used both in research and clinical practice for early detection of patients at risk of non-adherence and for identification of potentially modifiable barriers to medication adherence. The PEDIA has the potential to narrow the gap between the caregivers' and the patients' realities and support the implementation of individualized interventions to improve adherence. 


\section{Contributors}

C. C. Almeida-Brasil contributed to the work's conception and design, participated in data collection, performed the analysis of the data and interpretation of the findings and was responsible for drafting the paper and approved the manuscript's final version. E. Nascimento contributed to the study's design, participated in data analyses, in the article's writing and in the interpretation of the findings and approved the manuscript's final version. M. R. Silveira and P. F. Bonolo contributed to the study's design, critically reviewed the work and approved its final version. M. G. B. Ceccato contributed to the study's design and conception, participated in the drafting of the article and interpretation of the findings, and approved the manuscript's final version.

\section{Additional informations}

ORCID: Celline Cardoso Almeida-Brasil (00000002-6324-4702); Elizabeth do Nascimento (00000002-3244-2271); Micheline Rosa Silveira (00000001-7002-4428); Palmira de Fátima Bonolo (00000003-2744-7139); Maria das Graças Braga Ceccato (0000-0002-4340-0659).

\section{Acknowledgments}

The authors would like to express their appreciation to the participants of this study. The authors also thank all researchers involved in the ECOART study, as well as Minas Gerais State Research Foundation (Fapemig) and Pro-Rectory of Research of the Federal University of Minas Gerais (PRPq) for the financial support.

\section{References}

1. Quiros-Roldan E, Magoni M, Raffetti E, Donato F, Scarcella C, Paraninfo G, et al. The burden of chronic diseases and cost-of-care in subjects with HIV infection in a Health District of Northern Italy over a 12-year period compared to that of the general population. BMC Public Health 2016; 16:1146.

2. Joint United Nations Programme on HIV/ AIDS. UNAIDS data 2017. Geneva: Joint United Nations Programme on HIV/AIDS; 2017.

3. Cohen MS, Chen YQ, McCauley M, Gamble T, Hosseinipour MC, Kumarasamy N, et al. Prevention of HIV-1 infection with early antiretroviral therapy. N Engl J Med 2011; 365:493505.

4. World Health Organization. Consolidated guidelines on the use of antiretroviral drugs for treating and preventing HIV infection: what's new. Geneva: World Health Organization; 2013.

5. Supervie V, Viard JP, Costagliola D, Breban R. Heterosexual risk of HIV transmission per sexual act under combined antiretroviral therapy: systematic review and bayesian modeling. Clin Infect Dis 2014; 59:115-22.

6. Ford N, Darder M, Spelman T, Maclean E, Mills E, Boulle A. Early adherence to antiretroviral medication as a predictor of long-term HIV virological suppression: five-year follow up of an observational cohort. PLoS One 2010; 5:e10460.
7. Ritchie CW, Harrigan S, Mastwyk M, Macfarlane S, Cheesman N, Ames D. Predictors of adherence to atypical antipsychotics (risperidone or olanzapine) in older patients with schizophrenia: an open study of 3(1/2) years duration. Int J Geriatr Psychiatry 2010; 25:411-8.

8. Gerend MA, Shepherd MA, Shepherd JE. The multidimensional nature of perceived barriers: global versus practical barriers to HPV vaccination. Health Psychol 2013; 32:361-9.

9. Glasgow RE. Perceived barriers to self-management and preventive behaviors. Health behavior constructs: theory, measurement \& research. http://dccps.cancer.gov/brp/con structs/index.html (accessed on Sep/2018).

10. Fishbein M, Yzer MC. Using theory to design effective health behavior interventions. Commun Theory 2003; 13:164-83.

11. U.S. Department of Health and Human Services FDA Center for Drug Evaluation and Research; U.S. of Health and Human Services FDA Center for Biologics Evaluation and Research; U.S. Department of Health and Human Services FDA Center for Devices and Radiological Health. Guidance for industry: patient-reported outcome measures: use in medical product development to support labeling claims: draft guidance. Health Qual Life Outcomes 2006; 4:79. 
12. Engler K, Lessard D, Lebouché B. A review of HIV-specific patient-reported outcome measures. Patient 2017; 10:187-202.

13. Mills EJ, Nachega JB, Bangsberg DR, Singh S, Rachlis B, Wu P, et al. Adherence to HAART: a systematic review of developed and developing nation patient-reported barriers and facilitators. PLoS Med 2006; 3:e438.

14. Vervoort SC, Borleffs JC, Hoepelman AI, Grypdonck MH. Adherence in antiretroviral therapy: a review of qualitative studies. AIDS 2007; 21:271-81.

15. Bolsewicz K, Debattista J, Vallely A, Whittaker A, Fitzgerald L. Factors associated with antiretroviral treatment uptake and adherence: a review. perspectives from Australia, Canada, and the United Kingdom. AIDS Care 2015; 27:1429-38

16. Croome N, Ahluwalia M, Hughes LD, Abas M. Patient-reported barriers and facilitators to antiretroviral adherence in sub-Saharan Africa. AIDS 2017; 31:995-1007.

17. Coetzee B, Kagee A. The development of an inventory to assess the structural barriers to clinic attendance and pill-taking amongst users of antiretroviral therapy. AIDS Behav 2013; 17:319-28.

18. Genberg BL, Lee Y, Rogers WH, Wilson IB. Four types of barriers to adherence of antiretroviral therapy are associated with decreased adherence over time. AIDS Behav 2015; 19:8592.

19. Wohl DA, Panter AT, Kirby C, Magnus BE, Hudgens MG, Allmon AG, et al. Estimating HIV medication adherence and persistence: two instruments for clinical and research use. AIDS Behav 2018; 22:948-60.

20. Almeida CC. Dificuldades e facilidades associadas ao tratamento antirretroviral: autopercepção de pessoas vivendo com HIV em acompanhamento em serviços públicos de saúde do Brasil [Dissertação de Mestrado]. Belo Horizonte: Universidade Federal de Minas Gerais; 2014.

21. Almeida-Brasil CC, Ceccato MGB, Nemes MIB, Guimarães MDC, Acurcio FA. Improving community mobilization in HIV treatment management: practical suggestions from patients. Rev Panam Salud Pública 2017; 41:e119.

22. Almeida-Brasil CC, Nascimento E, Costa JO, Silveira MR, Bonolo PF, Ceccato MGB. Desenvolvimento e validação do conteúdo da escala de percepções de dificuldades com o tratamento antirretroviral. Rev Méd Minas Gerais 2016; 26 Suppl 5:S56-64.

23. Mendes JC, Bonolo PF, Ceccato MDGB, Costa JO, Reis AMM, Dos Santos H, et al. Adverse reactions associated with first-line regimens in patient initiating antiretroviral therapy. Eur J Clin Pharmacol 2018; 74:1077-88.

24. DeVellis RF. Scale development theory and applications. Newbury Park: Sage Publications; 2003. (Applied Social Research Methods Series, 26).
25. Nunnally JC, Bernstein IH. Psychometric theory. 3rd Ed. New York: McGraw Hill; 1994.

26. Muzaffar B. The development and validation of a scale to measure training culture: the TC Scale. Journal of Culture, Society and Development 2016; 23:49-58.

27. McDonald RP. Test theory: a unifed treatment. Mahwah: Lawrence Erlbaum Associates; 1999.

28. Trizano-Hermosilla I, Alvarado JM. Best alternatives to cronbach's alpha reliability in realistic conditions: congeneric and asymmetrical measurements. Front Psychol 2016; 7:769.

29. Reise SP, Scheines R, Widaman KF, Haviland MG. Multidimensionality and structural coefficient bias in structural equation modeling: a bifactor perspective. Educ Psychol Meas 2013; 73:5-26.

30. Timmerman ME, Lorenzo-Seva U. Dimensionality assessment of ordered polytomous items with parallel analysis. Psychol Methods 2011; 16:209-20.

31. Baglin J. Improving your exploratory factor analysis for ordinal data: a demonstration using FACTOR. Practical Assessment, Research \& Evaluation 2014; 19:1-15.

32. Lloret S, Ferreres A, Hernández A, Tomás I. The exploratory factor analysis of items: guided analysis based on empirical data and software. An Psicol 2017; 33:417-32.

33. Tabachnick BG, Fidell LS. Using multivariate statistics. 3rd Ed. New York: HarperCollins; 1996.

34. Samejima F. Graded response model. In: van der Liden WJ, Hambleton RK, editors. Handbook of modern item response theory. New York: Springer; 1996. p. 85-100.

35. Nguyen TH, Han HR, Kim MT, Chan KS. An introduction to item response theory for patient-reported outcome measurement. Patient 2014; 7:23-35.

36. Baker FB. The basics of item response theory. Washington DC: ERIC Clearinghouse on Assessment and Evaluation; 2001.

37. Koo TK, Li MY. A guideline of selecting and reporting intraclass correlation coefficients for reliability research. J Chiropr Med 2016; 15:155-63.

38. Lee J, Paek I. In search of the optimal number of response categories in a rating scale. Journal of Psychoeducational Assessment 2014; 32:663-73.

39. Grimbeek P, Bryer F, Beamish W, D’Netto M. Use of data collapsing strategies to identify latent variables in CHP questionnaire data. In: Bartlett B, Bryer F, Roebuck D, editors. Proceedings of 3rd International Conference on Cognition, Language, and Special Education. Brisbane: Griffith Research Online; 2005. p. 125-39.

40. Jeong HJ, Lee WC. The level of collapse we are allowed: comparison of different response scales in Safety Attitudes Questionnaire. Biom Biostat Int J 2016; 4:00100. 
41. Remien RH, Hirky AE, Johnson MO, Weinhardt LS, Whittier D, Le GM. Adherence to medication treatment: a qualitative study of facilitators and barriers among a diverse sample of HIV+ men and women in four US cities. AIDS Behav 2003; 7:61-72.

42. Ping W, Cao W, Tan H, Guo C, Dou Z, Yang J. Health protective behavior scale: development and psychometric evaluation. PLoS One 2018; 13:e0190390.

43. Tennant R, Hiller L, Fishwick R, Platt S, Joseph S, Weich S, et al. The Warwick-Edinburgh Mental Well-being Scale (WEMWBS): development and UK validation. Health Qual Life Outcomes 2007; 5:63.

44. Almeida-Brasil CC, Moodie EEM, McLinden T, Hamelin AM, Walmsley SL, Rourke SB, et al. Medication nonadherence, multitablet regimens, and food insecurity are key experiences in the pathway to incomplete HIV suppression. AIDS 2018; 32:1323-32.
45. Drachler ML, Drachler CW, Teixeira LB, Leite JC. The scale of self-efficacy expectations of adherence to antiretroviral treatment: a tool for identifying risk for non-adherence to treatment for HIV. PLoS One 2016; 11:e0147443.

46. Grangeiro A, Escuder MM, Cassenote AJ, Souza RA, Kalichman AO, Veloso VG, et al. The HIV-Brazil cohort study: design, methods and participant characteristics. PLoS One 2014; 9:e95673.

47. Silva JA, Dourado I, Brito AM, Silva CA. Factors associated with non-adherence to antiretroviral therapy in adults with AIDS in the first six months of treatment in Salvador, Bahia State, Brazil. Cad Saúde Pública 2015; 31:1188-98. 


\section{Resumo}

Este estudo teve por objetivo o desenvolvimento e avaliação de uma nova medida de desfecho relatada pelo paciente para avaliar barreiras percebidas à adesão à terapia antirretroviral (TARV). A escala Percepção de Dificuldades com o Tratamento Antirretroviral (PEDIA) foi desenvolvida com base em entrevistas com pacientes. Após teste piloto e avaliação de evidências com base no conteúdo do teste, revisões da escala resultaram em uma versão com 40 itens. A PEDIA foi aplicada em 415 adultos soropositivos para HIV que receberam TARV por um máximo de 180 dias, recrutados de três unidades de saúde de referência na cidade de Belo Horizonte, Minas Gerais, Brasil. As análises incluíram análise fatorial exploratória, consistência interna, teoria da resposta ao item, estabilidade temporal, e relação preditiva testecritério. A versão final da escala contém 18 itens distribuídos em três dimensões, no caso: problemas cognitivos e de rotina (4 itens); preocupações com medicamentos e saúde (6 itens); e medos e sentimentos do paciente (8 itens). Resultados do ômega de McDonald e estabilidade temporal demonstram que a PEDIA é internamente consistente e produz escores estáveis ao longo do tempo. As funções de informação do teste sugerem que as três dimensões foram informativas na avaliação de uma ampla gama do traço latente. Evidências relacionadas à relação teste-critério confirmaram que a PEDIA foi capaz de prever não-adesão três meses depois. Nossos resultados sugerem que a PEDIA é uma ferramenta robusta do ponto de vista psicométrico para a avaliação das barreiras percebidas por pacientes adultos que iniciam TARV. Ela pode ser usada em contextos clínicos e de pesquisa para a detecção precoce de pacientes em risco de não-adesão e para a identificação de barreiras potencialmente modificáveis.

Medidas de Resultados Relatados pelo Paciente; Psicometria; Infecções por HIV; Adesão à Medicação

\section{Resumen}

Este estudio se propone desarrollar y evaluar una nueva medida de resultados informados por los pacientes para evaluar los obstáculos percibidos en la adherencia a la terapia antirretroviral (ARV). Las barreras percibidas para la adherencia a la terapia antirretroviral según la escala Percepción de Dificuldades con el Tratamiento Antirretroviral (PEDIA) se desarrollaron basándose en entrevistas a pacientes individuales. Tras unas pruebas piloto, $y$ evaluando evidencias basadas en el contenido de las pruebas, las revisiones de la escala resultaron en una versión de 40 items. PEDIA se administró a 415 adultos infectados de VIH que recibian ARV durante un máximo de 180 días, captados en tres centros de salud de referencia en la ciudad de Belo Horizonte, Minas Gerais, Brasil. Los análisis incluyeron el análisis exploratorio factorial, la consistencia interna, la teoría de respuesta al item, estabilidad temporal, $y$ validez de criterio en las pruebas predictivas. La versión final de la escala final cuenta con 18 items distribuidos en las siguientes tres dimensiones: problemas cognitivos $y$ rutinarios (4 items); medicación y problemas de salud (6 items); además de miedos y sentimientos del paciente ( 8 items). Los resultados del omega McDonald y la estabilidad temporal demuestran que PEDIA es internamente consistente y obtiene puntuaciones estables en marcadores con el paso de los años. Las pruebas de información sugirieron que las tres dimensiones fueron informativas, evaluando un amplio abanico de características latentes. Las evidencias respecto a la relación entre las pruebas y los criterios confirmaron que PEDIA era capaz de predecir la no-adherencia tres meses después. Nuestros resultados sugieren que PEDIA es una herramienta psicométrica para evaluar los obstáculos percibidos en pacientes adultos que comienzan una $A R V$. Se puede utilizar tanto en el entorno de investigación, como en el de la práctica clínica para una detección temprana de pacientes con riesgo de no adherencia y la identificación de obstáculos potencialmente modificables.

Medición de Resultados Informados por el Paciente; Psicometría; Infecciones por VIH; Cumplimiento de la Medicación
Submitted on $24 / \mathrm{Sep} / 2018$

Final version resubmitted on 05/Dec/2018

Approved on 27/Dec/2018 